\title{
Stanislavski's creative state on the stage. A spiritual approach to the 'system' through practice as research
}

\section{Gabriela Curpan}

\begin{abstract}
This article is a continuation of a previously published one and talks about my own research project, with a focus on various meditation techniques, used as un underlying principle of breath to observe possible spiritual ways of preparing the actor towards what Stanislavski defines as the creative state or as experiencing 'the life of the human soul' on the stage. Following the odyssey of the artist from being oneself to becoming the character, my practice as research looks upon how certain spiritual ways (such as meditation) might contribute to their artistic development. It also draws attention on the strange similarities between Christian Orthodox ideas, the Zen Buddhist state of 'enlightenment'/ 'zanmai', and the Stanislavskian creative state.
\end{abstract}

Keywords: the 'system', the Orthodox Faith, Doukhobors, concentration, 'I am', meditation, kin-hin, the soul, creative state, zanmai, enlightenment, mindfulness.

Gabriela Curpan is an experienced Romanian professional actress who completed her $\mathrm{PhD}$ with Goldsmiths, University of London. Currently, she is a Senior Lecturer in Acting at University of Wolverhampton. Her practice as research explores various spiritual ways of preparing towards experiencing the creative state on the stage, as envisioned by Stanislavski.

\section{Introduction}

In January 2014, with the help of four professional actresses, I initiated the practical work of my research, intended to test possible ways towards experiencing the creative state on the stage, by questioning the presumed dualistic Cartesian way of training only the body and the mind of the artist, generally associated with Stanislavski's 'system'1. Thus, we began by looking upon the 
crucial importance of the 'soul' concept, largely present in Stanislavski's works, and which is clearly incompatible with the Cartesian type of thought. However, as I soon was to discover, this notion of the 'soul', without which it might be impossible to comprehend fully Stanislavski's legacy and its ways of application, seems to be intentionally excised from several translations, including Jean Benedetti's.’[...] not only replacing 'soul' with 'mind', but also eliminating 'spiritual' completely", Benedetti's translation appears to expunge any "evidence of a religious presence" from Stanislavsky's writings ${ }^{2}$.

As argued by Sharon Marie Carnicke, in Russia, in the 1920s, "the System itself—based upon the premise that there is an indissoluble link between mind and body, spirit and flesh", started to violate "the required materialistic philosophy" of the time. If "body and flesh were acceptable", mind, as in the unconscious could only remain questionable, while 'spiritual', 'soul', and 'spirit' became totally unacceptable ${ }^{3}$. It is crucial also to remember that "starting with 1938, as part of Stalin's policy of centralized control", the Moscow Art Theatre was forced to become "the model for all Soviet theatres, while Stanislavski's image and life-work were "included in a Stalinist pantheon". Therefore, due to the strict communist censorship, "through the lens of Soviet ideology", and in spite of the clear "holistic bond between body and spirit", Stanislavski looks to be "inaccurately portrayed as favouring the scientific over the spiritual"

As a Romanian actress who spent half of a lifetime under a similar totalitarian regime (Ceausescu's), I can relate to the necessity of secretly pursuing a spiritual life in order to avoid dire consequences. Therefore, I can conclude that the association with such a regime, and its ideology, might have been the main factor leading to the dissemination of a completely distorted vision and comprehension of Stanislavski's secret personal spiritual beliefs and ideals. At the core of his 'system', these appear not to have much in common with the communist materialistic ideology. Jerzy Grotowski, for example, considers this distortion to be "Stanislavski's assassination after his death" in so far as it presented a 'system' devoid of any spiritual thought ${ }^{6}$. This might have led to a worldwide acknowledgement of a realistic (cartesian) approach to the 
detriment of the spiritual one that envisions the soul/spirit of the artist as being central to experiencing the creative state.

Certain "instrumentalist appropriations of Stanislavski today [...] tend to use them exclusively for psychological realism", . However, considering that Stanislavski's "aesthetics as both an actor and a director revolved around the psycho-emotional and psychophysical aspects of human behaviour", the psychological realism might not represent the unique way in which the 'system' can be either explored or taught ${ }^{8}$. "Like many great artists, Stanislavski" constantly "navigates between these eternal poles, profane and sacred, rough and holy, earth and clouds, showbiz and sacrament" comfortable" for a while if she/he "ignores one pole"; yet this can ultimately lead "to artistic suicide" ${ }^{\prime 10}$.

Moreover, in Stanislavski's vision, "the task of training the actor is to develop" that inner spirit of "the human being who is the actor so that acting transcends play-acting and show". Undoubtedly, "the more the actor grows spiritually, the greater the resources of the actor become"11. Furthermore, "once a feel of this transcendence enters the actor's play, it surpasses banal technique to coalesce with the invisible dimension that powers human life". Clearly, "the preparation of actors was fundamental to Stanislavski”. Nevertheless, this necessary preparation was not directed exclusively towards technical training which, according to Maria Shevtsova, was equated by Stanislavski with "dressage", but more as a way of "the actor's thoughtful, conscious and probing 'work on himself",

As Shevtsova further explains, it might be no coincidence that, when establishing "the titles of his volumes on the subject of developing the actor", Stanislavski intentionally suggested 'that training in the sense of 'dressage', or, indeed, in the sense of 'tools', was far from his central aim" ${ }^{\prime 13}$. In addition, when reading his books, enough evidence can be found to support the thought that the 'system' was not at all designed specifically for a realist style, as labelled after the great success of The Moscow Art Theatre with the historico-realistic line. In Stanislavski's own statement: 
We were discussed in the press and in high society. We were labelled once and for all a realistic theatre, naturalist, of authentic precision and detail in our productions. This misunderstanding took root, is still alive to this day, although for the following quarter of a century we passed artistically through the most varied and divergent phases and lived through a whole series of reforms. [...] I was born and lived for the highest purposes of art. The historico-realistic line was only one, initial transient phase in our development $[\ldots]^{14}$.

There is no doubt in my mind that Stanislavski includes both the artist's and the character's souls in the creative processes. As such, his way of training, that might be intended not only for the artistic maturation of the actor but also for their spiritual development, cannot abide by the rules of the modern Cartesian dichotomy. While eliminating the idea of the soul, such rules tend to draw a clear distinction between body and mind, assigning "the immaterial contents" of the latter "to an immaterial mental subject"15.

As opposed to a Cartesian type of thinking, for Stanislavski, all these human aspects body, mind, and soul - appear to be equally real, working together in a perfect symbiosis. In his thought, "the bond between the body and the soul is indivisible. The life of the one engenders the life of the other, either way around"16. Moreover, all the aspects of the mind: conscious, unconscious, and superconscious provide the link between the physical being and the spiritual one ${ }^{17}$. He urges his students to ask themselves: "Can the first [physical being] exist without the second [spiritual being] or the second without the first?" The only possible answer in his mind is that all these aspects of a human being "cannot be alien to one another"; on the contrary, "their kinship and congruence are mandatory"18. Stanislavski was born and raised in the Christian Orthodox Faith ${ }^{19}$. He was an active practitioner of this faith for more than half of his life, at least until the 1917 Russian Revolution. Therefore, both as an Orthodox and an artist, he can only reject the Cartesian dichotomy noted above. In fact, transcending this split might be the first step towards the premises that can enable the actor better to prepare for experiencing the creative state on the stage. 


\section{Practical Explorations}

In order to explore the 'system' from a spiritual perspective, I could not limit my practice as research to a single aspect of an actor's journey (such as the training) for the exploration of all its stages, including the creation of the role (rehearsing) and the ephemeral existence of the character on the stage (performing), proved to be critical. These main stages observed were more or less linear, with the first one completely overlapping the remaining two. Yet, reaching the creative state only through this horizontal (linear) progression appeared to be insufficient in so far as a vertical observance of the practice became also crucial. Thus, the three stages noted above were developed with a whole examination of three more levels - 1. Creating the proper atmosphere; 2. Meditation as an underlying principle of breath; and 3. Observing/testing the elements of the 'system'.

Inspired by Stanislavski's sense of spirituality and his constant advice for the actor to follow specific ways of moral behaviour in order to grow artistically, these levels were rather spiritually orientated and became central for the successful experiencing of the creative state. However, at the outset of my research, driven by my desire to prove that there is indeed a spiritual dimension to Stanislavski's legacy, I had this tendency of accentuating the importance of the spiritual aspects to the detriment of the realist, tangible ones. To some extent, I was looking at both, as if they were two completely separate ways. And this proved to be a mistake, with no major breakthrough in the practice. Only later on, when grasping that, for Stanislavski, there might not be such a separation between technique and spirituality, things completely changed. The moment these two ways were considered together, with none more important than the other, the actresses participating in the research were able to change perspective, thus achieving some amazing results.

Mirroring (as much as possible) Stanislavski’s ways, my practice as research adapted various spiritual or religious principles to the work of the actor, both on their 'self' and on their role. Such principles were embedded in usable patterns of artistic beliefs and behaviour, while the ultimate purpose was never intended to exceed artistic spheres. By using this crucial 
Stanislavskian body-mind-soul continuum as a point of reference, I was guiding the actors towards a transformational journey of becoming. While on this path, the entity of the human being-student who, by accident, might stumble upon the creative state, slowly transforms into the entity of the human being-actor. Yet, although more skilled than the student, the arising actor is not necessarily ready to experience this state more often in so far as it is highly ineffable and utterly uncontrollable.

\section{The Creative State}

Concerned with his own struggles as an emerging actor, and profoundly unhappy with the nineteenth-century Russian general style of an actor's education, mainly teaching pupils "to read and act according to a demonstration", and thus giving them no other choice but simply to "copy their teachers", Stanislavski embarked upon what was to become the main goal of his life ${ }^{20}$. Stanislavski was mesmerised by "certain qualities" all the great actors he admired seemed to share $^{21}$ "there was a kind of aura around them on the stage",22. For Stanislavski, this is equated with the actor "getting into paradise", when they can "capture the very heart of a role" to "become the character" ${ }^{23}$. As he clearly states, the purpose of the whole 'system' "must serve as a threshold into the creative state, and one must learn to open, not close the door" 24 .

Carnicke compares this creative mood with the awareness "of a yogi who has reached a higher state of consciousness" ${ }^{25}$. Michael Chekhov describes it as a "happy moment", in which the actor reaches a particular inner freedom, whilst they—-the 'creator'-simultaneously become the 'observer' of their own creation ${ }^{26}$. In Peter Brook's account, it is an artistic 'act of possession" 27 . Grotowski considers the creative state to be the illusive moment in which "the actors are penetrated [...] by themselves" ${ }^{28}$. Nicolai Demidov draws an analogy between this state and the experience of driving "an automobile that's reached its greatest possible speed" 29 . As expressed by Giuliano Campo, "the creative way is individual, it is a way that puts the actor in contact with his/her own self, where life in art must be pursued with a pure heart", always seeking for the "creative seed, getting rid of selfishness, pride and envy"30. 


\section{Meditation-The Underlying Principle of Breath}

In my previous article, I was commenting upon the possible religious or spiritual influences on Stanislavski's legacy via his Orthodox connections and his well-known yogic fascination. Although unable to find any direct evidence, during my research, I started to notice other possible sources of inspiration. Highly interesting similarities between some of Stanislavski's ideas and Zen Buddhist principles, for example, can be spotted throughout his main works. It is, however, important to clarify that these might be, in fact, completely accidental or they might be related to the yogic and Hindu notions he employed. On the one hand, "all the schools of Mahāyāna Buddhism" from which Zen evolved, are based on a group of some of the oldest sutras from the Hindu texts known as Upanishads ${ }^{31}$. On the other hand, all forms of yoga are also based on the knowledge found in the Upanishads, including Raja yoga, known to have been extensively used by Stanislavski" ${ }^{32}$. "In the first Studio of 1912, he and Leopold Sulerzhitski, its leader, regularly used Hatha yoga and Raja yoga" ${ }^{\prime 3}$. In the light of this, it is only logical to conclude that, although indirectly, some of Stanislavski's yogic inspired ideas might share a common significance with the Zen Buddhist ones, specifically with the concept of 'enlightenment ${ }^{\text {, }}$.

During my research, to induce and maintain Stanislavski’s "liturgical mood backstage", as in the first level of the work (the atmosphere), I used ideas found mostly in practicing the Orthodox Faith, such as moral behaviour, selflessness, sacralisation of the space/costumes/props, or even sacrifice ${ }^{35}$. Yet, all of the above can also be found within the yogic or Buddhist practices and, as such, automatically could be extended to the next level of work - the principle of breath - employing meditation as the main way of preparing towards achieving readiness for the creative state. Thus, I was amazed to discover that two apparently opposed spiritual practices (the Orthodox Faith and yoga) were in fact compatible. Clearly, "Stanislavsky's adoption of the idea of prana for relaxation and breathing exercises" seemed not to be contradicted in any way by "his ingrained Orthodoxy", which "was at the heart of his concern with the "life of the human spirit ${ }^{\prime, 36}$. 
According to Vera Soloviova, the place where Stanislavski "made all his experiments and evolved what later became known as his System" was "the First Studio",37. He appointed Sulerzhitski "as the artistic and administrative director" ${ }^{38}$. It appears that Sulerzhitski's notesmade over a period of two years spent on his journey to Canada with the Doukhobors, a Russian religious sect forced into exile by the Tsarist government-strongly impressed Stanislavski. Resonating with the Hindu and Buddhist forms combined with Leo Tolstoy's religious ideas (Orthodox in their origin), the meditative practices of the Doukhobors, were based on daily morning meditation ${ }^{39}$. Thus, they seemed to follow a practice very similar to the one experienced either in a sesshin (a Zen religious retreat) or in a hesychastic Orthodox monastery.

A sesshin is mostly sheltered by a temple or a secluded holy place where, for a particular period of time, the aspirant follows a strict program of meditation, either sitting, walking, or through physical work, while sharing their experience with the small community ${ }^{40}$. Interesting to note is that, on land acquired by Stanislavski near Evpatoria, on the shores of the Black Sea, a similar "communal summer retreat" was created for the actors of the First Studio by Sulerzhitsky $^{41}$. While in the retreat, they had chores to do: "one was a cook, another [a] coachman, a third a housekeeper, a fourth a boatman", and so on ${ }^{42}$.

In a similar manner, to learn 'mindfulness', as in the constant focusing of the mind on every job at hand while being present in the moment, a Zen Buddhist practitioner combines seated and walking meditation with day-to-day activities and hard work. However, the same combination also used to be employed in some Orthodox monasteries such as Optina Pustyn. This famous monastery was a place often visited by "all the greatest writers of the nineteenth century-Gogol, Dostoyevsky, and Tolstoy among them"43.

To resume, one of the spiritual procedures - teaching the ways of silencing the mindthat will reflect on both the body and the actor's attitude towards it is the practice of meditation to enhance concentration and attention by means of exercising the will, while working with the mind, as well as the body. When applied to acting-training, meditation teaches how these unique 
human instruments can respond to a relaxed concentrated attention, and how the actors develop a certain sharpening of their senses, which enables communion and communication beyond words. In spite of the clear references to concentration and attention in all Stanislavski's books, as for example, "creative concentration and attention" or such as the "sensory concentration", which is "particularly necessary and particularly valuable [...] when establishing the 'life of the human spirit in a role"', the idea of meditation does not seem to be explained ${ }^{44}$. Yet, during the work at The First Studio, meditation was often employed for training purposes. Moreover, Stanislavski used Ernest Wood's book on concentration, "very popular in the early part of the twentieth century", and which "provides exercises in giving one's whole to an object" to reach an "expansion of concentration" "45. Alongside these exercises, however, the book also contains an ample 'Supplement on Meditation', thoroughly explaining the meditational processes in relation to concentration/attention. Surely Stanislavski, who "marked exercises in the book" and used them "in the system", could not have been completely unaware of this second section". As Gillett points out, Stanislavski employed both Hatha and Raja yogic practices. Whilst "Hatha aims for calm and relaxation" by means of "physical postures and balance (asana) and breath control (pranayama) [...] Raja focuses on mental control through concentration (dharana), visualization, observation and meditation" $" 47$.

At least three major ways of meditating were employed during my practice. These are: seated meditation, meditation in walking, and meditation in action. My choice to begin the training with the seated one was inspired by Stanislavski's own advice to his students/actors to remember "that the whole basis of" their own life, which is "respiration", is not only the basis of their "physical existence, but that respiration plus rhythm forms the foundation" of the entire "creative work" $"$. According to Stanislavski, they can "never become good actors" if they do not carry out the whole "work on rhythm and breathing [...] in full consciousness". Only this can lead to experiencing "a state of such complete concentration"49.

It is worth noting that, during my practice, I found exploring the last two ways of meditating (walking and in action) utterly necessary to eliminate a gap between the seated 
meditation and motion/action, as experienced in the early stages. Initially, although all my actors responded wonderfully to the seated meditation, after each session concluded, a problem seemed to arise repeatedly. More precisely, the moment they were standing up, ready to continue the work involving actions and the body, the actors appeared completely to forget about using what was gained during the previous meditational sessions. They were exhibiting this unexplained inability of connecting the mental state reached in meditation with any physical action. Consequently, a practical way of establishing the contiguity between meditation and action was needed.

In fact, similar gaps tended to repeat, in a pattern, every time a new phase of the work began, including when introducing improvised speech after silence or the fixed given text after enjoying the freedom of improvisation. Therefore, to find viable ways of successfully eliminating each of these gaps, I had to return constantly and relentlessly to our sessions of meditation. In addition, to cover all the three stages of an actor's work, it was necessary to introduce the usual meditational procedures within every acting exercise or étude explored. Thus, the meditational process become an underlying principle of breath that was designed to connect each phase of the work with the next: firstly, from stillness to motion/physical action; secondly, from silence to basic sound; thirdly, from this basic sound to improvised speech and, finally, from improvisation, to the use of the actual given line, as written by the author.

Following in Stanislavski's footsteps, within the first few months of the training stage, I guided my actors to use meditation as instructed by Yogi Ramacharaka in Hatha Yoga. Thus, they learned concentration on the movement of the breath through the body, without paying attention to the rush of thoughts flowing into the conscious mind. Because the very intention to eliminate thoughts by controlling them will automatically result in a sudden flood of other random thoughts, forcefully to silence the mind is almost impossible. The harder one struggles to clear the mind, the stronger the assault of these thoughts becomes. On the contrary, the mind needs to be tricked into silence. Thus, whenever the attention is guided towards something specific, such as the sensation of the air traveling through the body or the sound produced while 
inhaling/exhaling, the actor can become aware of a special silent space. This space of utter silence and stillness resides in between breaths, right at the end of the exhalation and the beginning of a new breathing cycle, being a natural space within which thoughts cannot exist.

To introduce the idea of the inner higher self (soul), I further adopted a more complex type of meditating. Presented by Ramacharaka in Raja Yoga, this meditation uses the inner imagination of the practitioner, as well as mantras ${ }^{50}$. I also encouraged my actors to use projections of mental images, such as a sphere of light placed in the centre of the heart, or rays springing forth from the heart centre, the eyes, or the tips of the fingers. The impetus of these images was to give the inner core a form and a place in the body or to give substance to elusive energy. With the purpose of enabling the conscious mind (egotistic 'I') to learn about, and accept, the reality of the unperceivable creative 'I' (soul) with its subtle energies, I guided the actors to use what I called the 'I am' affirmation ('I am a higher self, beyond my body or my mind') as a mantra ${ }^{51}$.

The second and third ways of meditating, as in the walking one and the meditation in action, were mostly observed through a silent étude, intended to draw a bridge between the practices of meditation during training and the actual creative processes employed while approaching a specific role. Based on movement/actions and envisioned as a symbolic ritual, this étude strived to use the seated, the walking, and the doing meditation/mindfulness in an artistic form. For example, following Stanislavski's instructions on how to walk on the stage (very similar to a specific Zen type of meditation), I initiated the work on the étude by simply teaching my actors meditation in walking. Known as the kin-hin, this Zen way of meditating is practised during the sessions of seated meditation (zazen) as a "walking exercise", helping the practitioner to relax the overstressed limbs without interrupting the inner concentration ${ }^{52}$.

Because Stanislavski uses astonishingly similar methods, to maintain a highly concentrated mind while testing different rhythms in movement, I constantly explored ways of walking in meditation. To analyse the flawless way in which an artist should walk on the stage, Stanislavski dedicates seven pages from An Actor's Work, 'Year Two: Embodiment-Physical 
Education' to a much similar practice. With the clear purpose of raising awareness of the necessity of learning how to walk when exposed to public scrutiny, Stanislavski observes the physical apparatus in movement. He concentrates on how to develop a flow-like type of walking enabled by an essential "flexibility of movement" that, with proper training, could become second nature ${ }^{53}$.

The Stanislavskian actor should explore inner awareness of the interdependence between body and spirit/energy while performing the simple action of walking in so far as "only through inner awareness of movement can we begin to understand and feel it" ${ }^{, 54}$. With this objective in mind, Stanislavski accentuates the importance of maintaining a straight body while slightly flexing the knees, in order to induce a slide-like motion that opposes the usual interrupted, jolted one. The correct use of every part of the leg, shoulders, and head, is further analysed in detail, perfectly mirroring the above-noted Zen Buddhist ways of the kin-hin practice.

\section{The Creative State versus Enlightenment}

Like Stanislavsky, Demidov seems to equate highly inspired moments of artistic creativity on the stage with what he calls "flashes of enlightenment". Demidov feels compelled to interrogate his students: "haven't you ever seen these flashes of enlightenment, when all of a sudden, you got this inkling - that's 'IT' ... this is 'IT!' ... Of course, you have! It's for these moments that you threw yourself into theatre in the first place" ${ }^{95}$.

When I was looking at how the creative state feels like (in my own experience and as described by various actors), I was able to make an interesting association. It appears that incredibly similar words tend to be used by Zen Buddhists when depicting short personal experiences of enlightenment. Both actors and Zen practitioners seem to acknowledge likewise states of mind, feelings, and perceptions. Could this mean that, by reaching the creative state, the actor may experience something as strong and transformational as the Buddhist 'enlightenment'?

Reaching enlightenment is the ultimate goal of Zen Buddhism, and it is considered to be the highest experience available to humankind ${ }^{56}$. It can be depicted as the achievement of a 
consciousness of one's true nature. However, as Hugo Enomiya-Lassalle points out, once attained, enlightenment does not imply a completion in practice. On the contrary, it needs to be experienced "again and again, until an ethical perfection has also been attained"57. This mirrors both the Orthodox pursuit of theosis and Stanislavsky's idea of a never-ending preparation of the actor towards spiritual and artistic growth, envisioned as climbing the endless symbolic ladder ${ }^{58}$.

Recalling a moment of enlightenment, as experienced while "waiting at leisure for the next train to Victoria Station", the American neurologist and Zen practitioner, James Austin, remembers that he was looking around at "the dingy interior of the station, some grimy buildings in the middle of the ground, and a bit of open sky above and beyond"59. Austin was only observing the scenery, with no particular thoughts in mind, when, all of a sudden, a consciousness of “Absolute Reality”, “Intrinsic Reality”, and "Ultimate Perfection” struck him. His experience was not limited to this awareness, but continued in waves, with a distorted perception of time and space. The second wave brought a feeling of "total understanding at depths far beyond simple knowledge", followed by the realisation that "no words exist to describe the depths and the qualities" of the gained insights ${ }^{60}$.

Lastly, Austin observed himself in his own person-James— "feeling totally released mentally" as well as "feeling especially good inside", entirely "revived and enormously grateful". There was also an inner "Wow!" present, "a big, silent exclamation mark", while the "expansion of capacities remained internalized" without proceeding into an "overtly exultant behaviour". Austin describes his feelings as "being awed, deepened, and calmed within a profound on-going intellectual illumination" ${ }^{\prime \prime}$. This sensation of a simultaneous consciousness of himself (the person changed by the experience) and himself (the observer), common to enlightenment, echoes Michael Chekhov's idea of the actor's split in consciousness during the creative state. All these indescribable feelings, the changed perception of time and space, as well as the sense of a double consciousness, were experienced during many acting exercises and études, more than once, by the actors involved in my practice as research. 
Another state of mind, attainable without practicing meditation, but which is recognized and highly esteemed by Zen Buddhists, is known as zanmai. As Enomyia-Lassalle asserts, this particular state is a "sign of approaching enlightenment", and it can be reached during any activity in which a person endeavours to become "completely absorbed and concentrated" 62 . After failing over and over through zazen (meditation), many Zen practitioners achieved enlightenment by experiencing zanmai when simply involved in their daily activities ${ }^{63}$. In addition, during zanmai, the consciousness is altered while "the inner person withdraws further and further from the outside world". Yet, this withdrawal does not alter the senses. On the contrary, "the person can see, hear and feel as usual". Even though their senses are sharper and clearer than ever, they are no longer "distracted by these sense perceptions",64. Moreover, a complete relaxation occurs. Nonetheless, being in fact combined with a highly attentive readiness, this relaxation has nothing in common with the kind achieved just before sleeping. Another important feature of zanmai is characterized by an alteration in the perception of time that can even extend to the feeling of no time. In Enomiya-Lassalle's opinion, "if [...] we are able to remain constantly in a state of zanmai, then it is possible to attain enlightenment at any time, even when we least expect it" ${ }^{\prime 65}$.

In the light of these statements, it can be easily deduced that both these Zen states are also available to the actor. According to Stanislavski, the actor must concentrate not only onstage but in life" in order to "notice and register everything that goes on around" $"$. As such, they may equally reach similar heights with the Zen practitioner who, by practicing 'mindfulness' or 'no mind' can experience both zanmai and enlightenment by concentrating on every single job at hand in their day-to-day activities. As explained by Austin, in order to understand the Zen concept of 'no mind', both activeness and passiveness, as fundamental aspects, have to be taken into account. Stanislavski's idea of experiencing the life and soul of the character as "I, here, today", by means of the 'I am', appears to bear uncanny similarities with this practice of mindfulness, leading to zanmai and enlightenment ${ }^{67}$. 
Enomiya-Lassalle speaks about a "meditative doing", as being "concentrated in the doing of every activity", no matter how simple and normal that particular activity might seem. As he explains, the secret resides in being present "in every situation" and in giving oneself "wholeheartedly to the matter at hand; not just physically, but with full mental alertness as well" ${ }^{\prime 68}$. On the same note, the Stanislavskian actor should exist at the centre of their created world, while allowing things to happen naturally, of their own accord. Instead of consciously reenacting a previous mechanically established construct, the actor needs to learn how to give themselves permission simply to react to these happenings.

Although related to the created life of the performance, as opposed to normal daily life, Stanislavski envisions this artistic existence as a sequential, uninterrupted, and logical line of actions or "throughaction". This needs to be grasped wholeheartedly, at all times when on the stage, in its inner and outer manifestations, while continuously living that life in body, mind, and spirit. Whilst the practitioner of Zen contemplates the unity of life in the everyday activity, the actor exists at the very centre of the created world of the performance and silently contemplates upon the unfolding of the life of their character. It can be concluded that any eventual differences mostly reside in the worlds to which Zen practices and the art of the theatre relate.

\section{Conclusion}

It is important to note that the constant repetition of all the meditational sessions equally have the purpose of entering and maintaining the relaxed and indescribable special awareness crucial to experiencing the creative state, again and again. This repetition may help the actors increasingly to familiarise with such awareness, up to the point at which it becomes second nature. By repeating gestures done in meditation - such as closing the eyes and taking a deep breath - the relaxed and concentrated state can be triggered at will. Both actions can become natural stimuli for instantly entering deep concentration. Later on, the actors no longer need to meditate before every rehearsal because their conscious mind can remember the feeling of being relaxed while highly concentrated, learned during meditation, and immediately responds to the 
stimuli employed. Alongside enhancing concentration, the practice of seated meditation also provides a primary understanding of the concept of inner action, simply because the conscious mind is, in fact, concentrated on a physical action, as in breathing. However, in order to achieve a better grasp of the strong connection between meditation and action, the actor should also be able consciously to make use of a similarly silent mind and a relaxed body while engaged in movement, or when performing different actions.

After testing all these types of meditating, with the purpose of enabling a body-mind-soul continuum awareness, by making use of the breath as an underlying principle of the whole practice, it became obvious that meditation, in all its explored forms, can be a crucial and powerful instrument for achieving embodied perception and acceptance of a possible inner “creative 'I"” (soul $)^{69}$. Furthermore, through constant exercise, the initially controlled-breathing process becomes second nature, and the actor is brought to a point in which they again can breathe freely. However, this time, the natural breath is accompanied by a strong awareness of both themselves and their own creation. By simply breathing, the artist can feel a slight connection with their inner creative ' $I$ ' and, thus, they are enabled to accept the natural subordination of their mind and body to this creative 'I' (soul). Becoming aware of the breath, the actor also learns to master such elements as 'concentration' and 'attention' by means of exercising a free 'will'. They also begin to feel and control the inner flow of energy/prana for, all these elements, pertaining to the processes of meditation (known to be key component elements of Stanislavski's 'system'), are utterly connected to each other, working hand in hand towards experiencing the creative state.

\section{Acknowledgements}

Many thanks to my supervisor, Professor Maria Shevtsova, for the unending patience, her constant guidance, and invaluable help. Also, a huge thank you to the amazing team of actors participating in my research, for their hard work and commitment. 
1 According to Gordon Baker, Cartesian dualism evolved from the philosophy of Rene Descartes, and "is commonly used to set the agenda of philosophy of mind" (Baker and Morris, 1996, 2).

${ }^{2}$ Curpan, 2019, 202-203

${ }^{3}$ Carnicke, 2009, 102

${ }^{4}$ Benedetti, 199, xiii

${ }^{5}$ White, 2006, 81

${ }^{6}$ Grotowski in Kumiega, 1987, 110

${ }^{7}$ Shevtsova, 2014, 335

${ }^{8}$ Ibid., 335

${ }^{9}$ Donnellan in Stanislavski, 2010, xi

${ }^{10}$ Ibid., xi

${ }^{11}$ Shevtsova, 2014, 336

${ }^{12}$ Ibid., 336

${ }^{13}$ Ibid., 336

${ }^{14}$ Stanislavski, 2008a: 184-185

${ }^{15}$ Foster, 199, ix

${ }^{16}$ Stanislavski, 2008b, 228

${ }^{17}$ Sergei Tcherkasski argues that Stanislavsky acknowledged an utter "connection between the creative state and unconsciousness, borrowing the notion of superconsciousness, as the source of inspiration, creative intuition, and transcendental knowledge" straight from Raja Yoga (Tcherkasski, 2012, 18). Somewhere else, Tcherkasski explains that "Yoga helped to formulate the core concept of the System about the unconscious and its division into the subconscious and the superconscious" (Ibid., 2016, 112).

${ }^{18}$ Stanislavski, 2008b, 207

${ }^{19}$ Magarshack, 1986, 3

${ }^{20}$ Stanislavski, 2008a, 61 
${ }^{21}$ Gordon in Curpan, 2019, 212

${ }^{22}$ Gordon states that "the performances of these actors reminded Stanislavski of the absolute absorption and rapture children feel when building sandcastles [...]. Time and place transform themselves" (Gordon, 1988, 28).

${ }^{23}$ Stanislavski, 2008a, 121

${ }^{24}$ Stanislavski in Carnicke, 2009, 169

${ }^{25}$ Carnicke, 2009, 130

${ }^{26}$ Chekhov, 1991, 155

${ }^{27}$ Brook, 1990, 123

${ }^{28}$ Grotowski in Brook, 1990, 123

29 As for the driver, who cannot think of something else but: "I hope I don't crash into anything or break my neck!", the "actor who's at the highest stage of his creative potential" cannot suddenly stop to analyse the experience. They can only live it, with the hope of "blazing past everything in one piece and not crashing into anything" (Demidov, 2016, 639). The artistic creation becomes an entity in its own. As such, its manipulation and conscious control seem no longer to be within the actor's power.

30 As Campo argues, "anticipating Grotowski, Stanislavski explains the need to unblock the individual energies in order to establish a spiritual contact between actors and spectators, that achieve a unity in beauty, something that is common to all human beings" (Campo, 2017, 184$185)$.

${ }^{31}$ Dumoulin, 2005, 34

${ }^{32}$ As Linda Brown Holt informs, Zen is grounded in Raja yoga in so far as its central principles: "dharana, keeping the mind focused on a thought or object; dhyana, meditation; and samadhi, superconscious experience" are also key components of Buddha's 'Eightfold Path' on which Zen is based (Brown Holt, 1995, 1).

${ }^{33}$ Gillett, 2007, 35

34 In Shunryu Suzuki's thought, the enlightenment is a state of mind reachable "beyond rationality", with a rush of "intuitive insight" in which the person gains "not only universal knowledge but clarifies issues of personal existence" followed by a happy "feeling of exaltation", utterly ineffable, in which one finds it difficult to describe the experience. It also comes with "changes in the boundaries of time and space", insofar as the normal perception of time disappears, being replaced by 'a sense of 'eternity' and 'infinity', while 'the old mental 
boundaries drop out' and the physical space is perceived as limitless" (Suzuki, 1970, 27). The event is accompanied by a "persisting positive change in attitude and behaviour" (Austin, 1999, 543).

${ }^{35}$ Stanislavski, 2010, 572

${ }^{36}$ Shevtsova, 2014, 337

${ }^{37}$ Soloviova in Gray, 1964, 137

${ }^{38}$ Tcherkasski, 2012, 5

39 Assuming a relaxed position, the Doukhobors used to sit down and meditate on the day ahead, imagining and visualizing better ways in which to fulfil all the tasks of the day, step by step (Tcherkasski, 2016, 31) - a process later used by Stanislavski in his acting exercises, mainly the ones designed to train the imagination. In An Actor's Work, Tortsov encourages his students "to see pictures with" what he calls the "mind's eye. In our actors' jargon we call these mental images, the inner eye" (Stanislavski, 2010, 73).

${ }^{40}$ Austin, 1999, 138

${ }^{41}$ Using the experience gained during his travels with the Doukhobors, Sulerzhitsky established "a quite strict regimen" in which, alongside acting exercises inspired by yoga, as well as the Doukhobors' way of meditating, the students shared a different "communal responsibility" (White, 2006, 79).

${ }^{42}$ White, 2006, 79

43 "The phenomenon of the Optina Startzy" represented a rebirth, "in the midst of the nineteenth century", of "the ancient hesychastic prophetic character" (Meyendorff, 1974, 160), and "a return to the hesychastic path of Russia's most revered medieval monks" (Figes, 2002, 292). Dostoyevsky describes in his "The Brothers Karamazov, the setting and atmosphere of Optina in detail". Moreover, "something of the character of Zosima reappears in the famous Starets Ambrose, who from 1873 to 1891 succeeded Father Leonidas and Father Macarius, the founders of the institution of the startzy at Optina" (Meyendorff, 1974: 160).

${ }^{44}$ Stanislavski, 2010, 90-111

${ }^{45}$ Whyman, 2013, 27

${ }^{46}$ Whyman, 2008, 85-86

${ }^{47}$ Gillett, 2014, 10-11

${ }^{48}$ Stanislavski, 1967, 168 
${ }^{49}$ Ibid., 168

50 Mantras are short affirmations that the meditators have to repeat in their own minds, while concentrating on the words uttered, instead of the breath.

51 As an alternative to the term 'ego', Stanislavski often uses "the egotistic 'I'". This notion completely opposes the "creative 'I"', as in the self/soul of the artist (Stanislavski, 1967, 111).

52 According to Enomiya-Lassalle, the correct practice of the kin-hin should be observed as follows: "The gaze is directed towards the floor, about three metres ahead". It starts with "the right foot", moving "half a step forward". When lowering it, the foot should become "almost anchored to the ground". Moreover, "as the foot is put down, the leg straightens, and the weight is shifted onto it". Also, "the chin is always pushed slightly in and the shoulders hang naturally. It should feel as though one were pushing up through the ceiling with the top of the head" (Enomiya-Lassalle, 1995, 30).

${ }^{53}$ In Stanislavski's mind, the actors or the dancers that master it "don't dance, don't play, they are what they do". Further, "if they were to pay genuine attention to the things they are feeling, they would be aware of the energy inside them, stemming from their secret depths, from their heart of hearts. It courses through the whole body". For Stanislavski, "only that kind of movement is right for the artistic embodiment of the life of the human spirit of the role" (Stanislavski, 2010, 365).

${ }^{54}$ Stanislavski, 2010, 365

${ }^{55}$ Demidov, 2016, 29

56 In Shunryu Suzuki's thought, the enlightenment is a state of mind reachable "beyond rationality", with a rush of "intuitive insight" in which the person gains "not only universal knowledge but clarifies issues of personal existence" followed by a happy "feeling of exaltation", utterly ineffable, in which one finds it difficult to describe the experience. It also comes with "changes in the boundaries of time and space", insofar as the normal perception of time disappears, being replaced by "a sense of 'eternity' and 'infinity', while 'the old mental boundaries drop out' and the physical space is perceived as limitless" (Suzuki, 1970, 27). The event is accompanied by a "persisting positive change in attitude and behaviour" (Austin, 1999, 543).

57 The key to enlightenment, according to Suzuki, resides in paying constant attention to one's "physical body". If the body slumps, the mind will automatically wander about, losing the self". Thus, the practitioner will not be present in their own body; thus, they cannot be present in the moment and, as Suzuki asserts, "this is not the way. WE MUST EXIST RIGHT HERE, RIGHT NOW! This is the key point" (Suzuki, 1970, 27).

${ }^{58}$ Known in the Orthodox Faith as theosis or deification, the real purpose of life is understood as a continuous journey of creation seeking a spiritual transformation through love and "the attainment of the grace of the Holy Spirit"; and it is envisioned as climbing a symbolic ladder 
(Berdyaev in N Lossky, 1952, 1). Reminiscent of Jacob's Biblical dream of a heavenly ladder, the Orthodox one is formed of thirty steps, being also the symbol of Christ, "the mystic ladder", as a gift and a sacrificial Godly act, to reveal to the ways of transcendence by means of theosis/deification (Coniaris, 1998, 190).

${ }^{59}$ Austin, 1999, 537

${ }^{60}$ Ibid., 537

${ }^{61}$ Ibid., 538-539

${ }^{62}$ Enomyia-Lassalle, 1995, 40

63 In ordinary life, most of the time, the will, the reason, and the memory seem to work separately. With the exception of "impulsive decisions", usually one tends to make a conscious choice only after being "reminded of something" and can reflect upon it. In deep concentration (while experiencing zanmai), however, the consciousness is joined with the will, the reason, and the memory and, as such, "the depths of the soul are touched, and acts are not fixed, but born" (Enomiya-Lassalle, 1995, 40).

${ }^{64}$ Enomyia-Lassalle, 1995, 40

${ }^{65}$ Ibid., 1995, 41-42

${ }^{66}$ Stanislavski, 2010, 11

${ }^{67}$ Ibid., 1989, 7

${ }^{68}$ Enomiya-Lassalle, 1995, 42

${ }^{69}$ Stanislavski, 1967, 111

\section{Bibliography:}

Arseniev, Nicholas. Russian Piety. Translated by A Moorhouse, The Faith Press, New York, 1975

Austin, $\mathrm{H}$ James. Zen and the Brain-Toward an Understanding of Meditation and Consciousness, MIT Press, Cambridge, Massachusetts and London, 1999

Baker, Gordon. Morris J Katherine. Descartes' Dualism, Routledge, London and New York, 1996

Benedetti, Jean. Stanislavski an Introduction. London: Methuen Drama, London, 1989

Benedetti, Jean. Stanislavski and the Actor. The Final Acting Lessons. London: Methuen Drama, 2008 
Benz, Ernst. The Eastern Orthodox Church, Its Thought and Life. Translated by C Winston and R Winston. Chicago: Aldine Publishing Company, 1963

Berdyaev, Nikolai. The Meaning of the Creative Act. Translated by Donald Lowrie. New York: Harper \& Brothers, 1998

Brown Holt, Linda. 'From India to China: Transformations in Buddhist Philosophy' The Journal of Traditional Eastern Health \& Fitness, [available online at http://www.thezensite.com/ZenEssays/HistoricalZen/FromIndiatoChina.htm] [accessed on 24/07/2016] 1995

Chekhov, Michael. On the Technique of Acting, edited by Mel Gordon, Quill-A Harper Resource Book, New York, 1991

Campo, Giuliano. 'After theatre, beyond the self. A pedagogy of life from Stanislavski to Grotowski', Stanislavski Studies, Vol. 5, No. 2 (2017), 173-195

Carnicke, Sharon Marie. Stanislavsky in Focus; an Acting Master for the Twenty-First Century. Abingdon: Routledge, 2009

Clarke, Peter G.H. 'Neuroscience, quantum indeterminism and the Cartesian soul' Brain and Cognition (2014), Volume 84, February, Issue 1, pp. 109-117

Climacus, St John. The Ladder of Divine Assent. Translated by Archimandrite Lazarus Moore. London: Faber and Faber, 1959

Coniaris, Anthony. Philokalia the Bible of Orthodox Spirituality. Minneapolis: Light and Life Publishing Company, 1998

Curpan, Gabriela. 'The influence of Christian Orthodox thought on Stanislavski's theatrical legacy', Stanislavski Studies, Vol 7, issue 2, pp. 201- 217, 2019

Demidov, Nikolai. Becoming an Actor-Creator. Edited and translated by Malaev-Babel, Andrei and Laskina, Margarita, London: Routledge, Taylor \& Francis Group, 2016

Des Chene, Dennis. 'Eternal truths and the laws of nature', (manuscript), [available on-line at: < https://philpapers.org/archive/DESETA.pdf> (August 2005)

Dumoulin, Heinrich. Christianity Meets Buddhism. Translated by John C Maraldo. La Salle Illinois: Open Court Publishing Company, 1974

Enomiya-Lassalle, Hugo. The Practice of Zen Meditation, edited by Roland Ropers and Bogdan Snela, translated by Michelle Bromley, Harper Collins, London, 1995

Fedotov, Georgy Petrovich (ed.). A Treasury of Russian Spirituality; Spiritual Masters. Translated by H Iswolsky. London: Sheed \& Ward Ltd, 1981

Gillett, John. Acting on Impulse. Reclaiming the Stanislavski Approach (Methuen Drama, London, 2007)

Gordon, Mel. The Stanislavsky Technique: Russia-A Work Book for Actors. New York: Applause Theatre Book Publishers, 1988 
Gray, Paul. 'The Reality of Doing: Interviews with Vera Soloviova, Stella Adler and Sanford Meisner' The Tulane Drama Review 9. No. 1 (1964) 136-155

Kumiega, Jennifer. The Theatre of Grotowski, Methuen, London, 1987c

Lossky, Nikolai. History of Russian Philosophy George Allen and Unwin Ltd, London, 1952

Lossky, Vladimir. The Mystical Theology of the Eastern Church. Cambridge James Clarke \& Co Ltd, 1973

Magarshack, David. Stanislavski: A Life. London: Faber and Faber Ltd, 1986

Meyendorff, John. St Gregory Palamas and Orthodox Spirituality. Translated by Adele Fiske. United States: St Vladimir's Seminary Press, 1974

Ramacharaka, Yogi. A Series of Lessons in Raja Yoga, LN Fowler \& Co Ltd, London, 1972

Ramacharaka, Yogi. Hatha Yoga, Pilgrims Publishing, Varanasi, 2008

Senelick, Laurence. Stanislavski-A Life in Letters. London: Routledge, Taylor \& Francis Group, 2014

Shevtsova, Maria. 'Actor to Performer/Doer: Theatre Quarterly, Vol. 30, Issue 4 (November 2014, 333-340)

Stanislavski, Konstantin. Stanislavski on the Art of Stage. Translated and edited by David Magarshack. London: Faber and Faber, 1967

Stanislavski, Konstantin. Creating a Role. Translated by E Raynolds Hapgood and edited by H Popper. New York: Routledge, Theatre Arts Books, 1989

Stanislavski, Konstantin. My Life in Art. Translated and edited by Jean Benedetti. London: Routledge Tailor \& Francis Group, (2008a)

Stanislavski, Konstantin. Stanislavski's Legacy, Translated by E Raynolds Hapgood. London: Eyre Methuen, (2008b)

Stanislavski, Konstantin. An Actor's Work: A Student's Diary. Translated and edited by Jean Benedetti. London: Routledge Tailor \& Francis Group, 2010

Suzuki, Shunryu. Zen Mind-Beginner's Mind, Edited by Trudy Dixon, Weatherhill, London and Boston, 1970

Tcherkasski, Sergei. 'Fundamentals of the Stanislavsky System and Yoga Philosophy and Practice' Stanislavsky Studies [e-Journal] [available online at http://stanislavskistudies.org/issues/issue-1/fundamentals-of-the-stanislavski-system-andyoga-philosophy-and-practice/] [accessed on 22/10/2014] (2012) 190-236

Tcherkasski, Sergei. Stanislavsky and Yoga, Translated by Vreneli Farber, Routledge Taylor \& Francis Group, London and New York, 2016

White, Andrew. 'Stanislavsky and Ramacharaka: The Influence of Yoga and Turn-of-theCentury Occultism on the System' Theatre Survey 47: 1 (2006) 73-92 
Whyman, Rose. The Stanislavsky System of Acting: Legacy and Influence in Modern Performance. Cambridge: Cambridge University Press, 2008

Wood, Ernest Edgerton. Concentration an Approach to Meditation, Quest Books, Theosophical Publishing House, Wheaton, Illinois and Chennai (Madras), India, 1900 